Florida International University FIU Digital Commons

7-17-2012

\title{
Why Is This Wave Different From All Other Waves? Jewish Miami: The Changing Face of Institutional Interaction in Three Phases
}

Ariella Siegel

Florida International University, asieg002@fiu.edu

DOI: $10.25148 /$ etd.FI12080624

Follow this and additional works at: https://digitalcommons.fiu.edu/etd

\section{Recommended Citation}

Siegel, Ariella, "Why Is This Wave Different From All Other Waves? Jewish Miami: The Changing Face of Institutional Interaction in Three Phases" (2012). FIU Electronic Theses and Dissertations. 700.

https://digitalcommons.fiu.edu/etd/700 


\section{FLORIDA INTERNATIONAL UNIVERSITY \\ Miami, Florida}

WHY IS THIS WAVE DIFFERENT FROM ALL OTHER WAVES?

JEWISH MIAMI: THE CHANGING FACE OF INSTITUTIONAL INTERACTION IN

THREE PHASES

A thesis submitted in partial fulfillment of the

requirements for the degree of

MASTER OF ARTS

in

RELIGIOUS STUDIES

by

Ariella Michal Siegel

2012 
To: Dean Kenneth G. Furton

College of Arts and Sciences

This thesis, written by Ariella Michal Siegel, and entitled Why Is This Wave Different From All Other Waves? Jewish Miami: The Changing Face of Institutional Interaction in Three Phases, having been approved in respect to style and intellectual content, is referred to you for judgment.

We have read the thesis and recommend that it be approved.

Ana Maria Bidegain

Alex Stepick

Oren Baruch Stier, Major Professor

Date of Defense: July 17, 2012

The thesis of Ariella Michal Siegel is approved.

Dean Kenneth G. Furton

College of Arts and Sciences

Dean Lakshmi N. Reddi

University Graduate School

Florida International University, 2012 


\section{DEDICATION}

To my friends, family, and colleagues who have supported me through all of this, I can't thank you enough. You gave me the strength to carry on and the drive to succeed. 


\section{ACKNOWLEDGMENTS}

A special thank you goes out to Valeria Schindler and A.J. Cohen, without whom this never would have been possible. I am in deep gratitude for the support, advice, and friendship you have given me throughout this process.

I would also like to thank Dr. Stier, without whom this would have never happened.

Thank you for your help, guidance, and mentoring. You have been a great influence on me and a huge help with my graduate schooling. 


\begin{abstract}
OF THE THESIS
WHY IS THIS WAVE DIFFERENT FROM ALL OTHER WAVES?

JEWISH MIAMI: THE CHANGING FACE OF INSTITUTIONAL INTERACTION IN

THREE PHASES

by
\end{abstract}

Ariella Michal Siegel

Florida International University, 2012

Miami, Florida

Oren Baruch Stier, Major Professor

This thesis presents an historical overview of the immigration/migration process that led to the institutional establishment of a vibrant Jewish community in Miami, Florida. By doing so, this thesis suggests three distinct, yet interconnected waves of immigration/migration: the first wave was from the 1920s until the 1950s and was comprised primarily of Northeastern Jewish migrants; the second wave was from the 1960s until the 1970s and was comprised of Cuban-Jewish immigrants; and the third wave began in the 1970s and continues until today, and is comprised of the Latin American Jewish immigrants. These waves are studied by considering (1) the demographics of each individual wave and the corresponding reasons for migration to Miami; (2) which institutions were established within each wave and the motivation for their establishment; and (3) the different dynamic each immigrant/migrant cohort had with the institutions in the Jewish community. It also explores institutional evolution within each wave and connects the waves together to reveal a multi-faceted construction of the Jewish community of Miami as it is today. 


\section{TABLE OF CONTENTS}

CHAPTER

PAGE

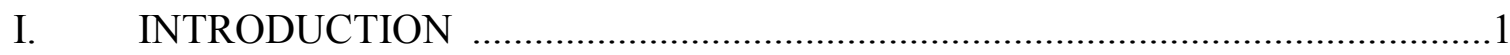

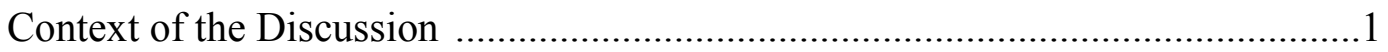

Scope of Research and Limitations....................................................................

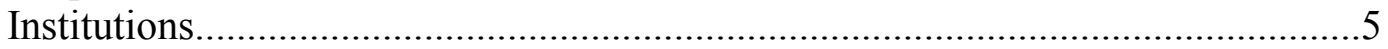

Theoretical Framework: Ethnic Communities and Religion ....................................

First Wave Theoretical Framework ..........................................................

Second Wave Theoretical Framework ………………................................

Third Wave Theoretical Framework ........................................................9

Jewish Community Theoretical Framework ..............................................................11

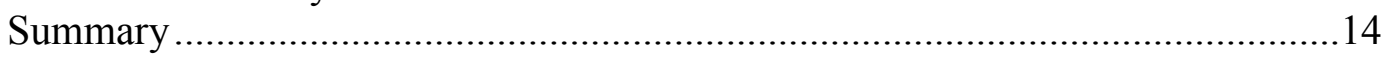

II. THE FIRST WAVE OF JEWISH IMMIGRATION ............................................16

Pre-First Wave Jews in Miami..........................................................................17

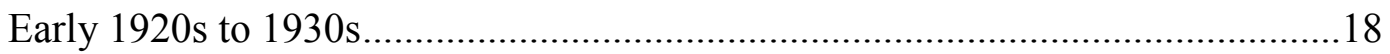

Community Institutional Establishment .................................................19

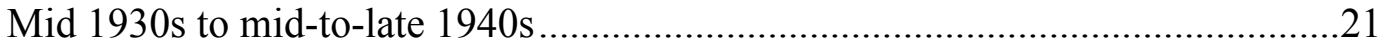

Community Institutional Establishment .................................................22

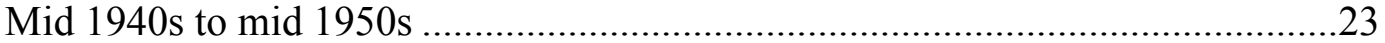

Community Institutional Establishment ..................................................27

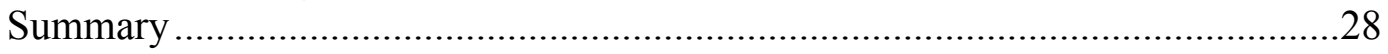

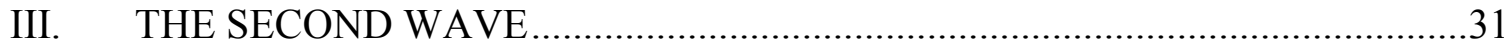

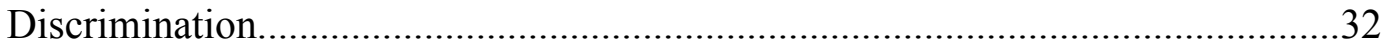

Composition of Community......................................................................

Community Institutional Establishment ......................................................35

Transition and Integration.............................................................................

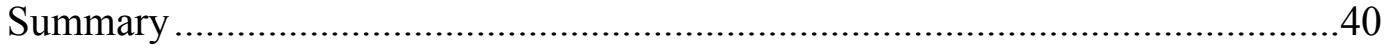

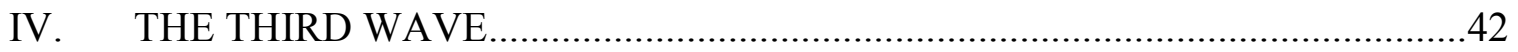

Community Institutional Establishment ...................................................49

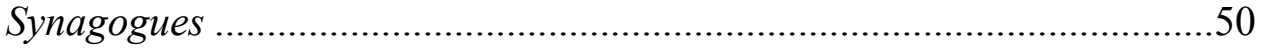

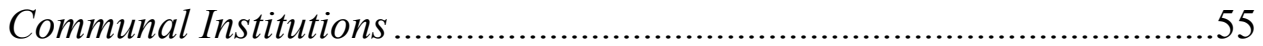

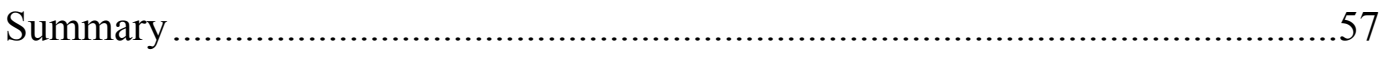

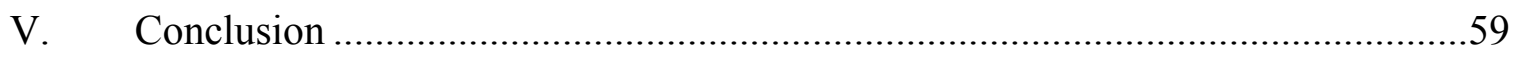

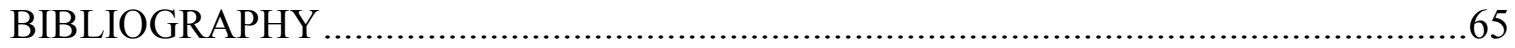




\section{CHAPTER I: INTRODUCTION}

When we arrived at the train station in Miami, a taxi took us to Miami Beach. As we rode over the causeway, I could hardly believe my eyes. To me, being at a summer place in the winter was a great event...Everything -- the buildings, the water -- had an indescribable glow and brightness to it. The palm trees especially made a great impression on me.

-Isaac Bashevis Singer, Jewish winner of the Nobel Prize in Literature

While Miami is known by most for its palm trees, sunny beaches and warm calming ocean breezes, it is also known by many as a city with a strong and vibrant Jewish community, which has contributed greatly to its success and growth. Miami is a city with a long history of Jewish immigration/migration, and today has a robust and interconnected network of synagogues, schools, hospitals, and community centers, among other institutions.

My thesis explores that long history and analyzes how three distinct waves of immigration/migration have helped to develop the Jewish institutions found within the city.

\section{Context of Discussion}

The primary purpose of this thesis is to analyze the interaction between immigrants/migrants and institutions through three waves of immigration/migration and how this interaction has shifted throughout each wave. The examination of this interaction was done by looking at the institutions established in each wave, the impetus for their foundation, and the subsequent relationship between the institution and the Jewish community. 
I define three waves of Jewish immigration/migration to Miami: the first wave began in the 1920s and lasted until about the mid-1950s, and was largely comprised of Jews from the Northeast United States, because of a continued economic boom and the development of the South Beach area; the second wave occurred in the 1960s, when approximately 5,000 Cuban Jews sought refuge in South Florida after Fidel Castro came to power; and the third wave, which is still occurring today, has been taking place since the late 1970s, when many Latin American immigrants came to Miami as a result of war or economic hardship in their own countries.

My hypothesis is three-fold and interconnected: the first wave of migrants needed to establish their own institutions when they first arrived in Miami. Establishing institutions was important because before this wave, no cohesive Jewish community existed. Despite the discrimination and limitations placed upon the new-found Jewish community, the first wave survived and eventually thrived, building numerous institutions for a bourgeoning community. The second wave experienced a similar version of discrimination and limitations that the first wave experienced; however, the discrimination was coming from the first wave itself, the existing Jewish community. Although the second wave starts out mirroring the first wave, by having to overcome discrimination and build a community of its own, by the end of the second wave, there is a shift. What truly differentiates the second wave from the first wave is that the second wave was eventually able to integrate itself into the already established Jewish community, whereas the first wave was not afforded that option, as no community existed previously. This ability to integrate allowed for the second wave to then build upon and contribute to the community. Finally, the last and most current wave has found 
itself arriving to an already established institutional community. The existing Jewish community however, has shifted to not only accommodate the needs of the new immigrants, but actually implement the institutional models they used in Latin America. I prove this by showing an historical overview of institutional establishment per wave of immigration, and the community's institutional reaction and subsequent response to the influx of new Jewish immigrants.

In order to paint a better picture, I begin by looking at the components that make up a Jewish community. Then, in an attempt to address the issues of which types of Jews immigrated/migrated to Miami and the motivating factors behind these immigrations/migrations, I look at immigration/migration patterns to South Florida as well as the demographics of the Jews who arrived there. I will also be looking at what institutions they founded as a basis for their Jewish community/ies, the impetus for their foundation, and how they contribute to the broader picture of the Miami Jewish institutional profile as of today. Lastly, I will look at the shifts in the relationship between the Jewish community and the institutions within each of these waves.

\section{Scope of Research and Limitations}

The reasons for the immigration/migration to and settlement in Miami, as well as the interaction between (im)migrants and the existing community are multi-dimensional and complex. Aspects that affected these issues were those such as the evolution of Miami as a city, non-Jewish Latin American immigration to Miami, as well as economics, politics, and social geography. The growth of Miami as a city correlates to the increase in the population of the Jewish community, as well as the development of other non-Jewish 
institutions. The Jewish community may be seen as a reflective microcosm of the larger evolution of the city of Miami, however, due to the scope of my research, I can only briefly acknowledge these factors, and address them later on in my thesis. 


\section{Institutions}

In giving a brief historical background of some key institutions, I refer to Jewish institutions and organizations, such as schools, synagogues, community centers, hospitals, social welfare and aid societies, political organizations, and men's and women's clubs. For the purposes of this paper, institutions, organizations, synagogues, etc. will be referred to as "institutions" only and will be categorized as social, religious, social welfare (health, etc.), and educational. They will include community-based/directed synagogues, day schools/educational institutes, Jewish Community Centers, Jewish Federations, and Jewish Family Service/social service agencies.

\section{Theoretical Framework: Ethnic Communities and Religion}

For my theoretical framework, I reference theories on ethnic communities and religion. The two books from which I derive my theoretical matrix are Immigrant America, a Portrait, by Alejandro Portes and Rubén G. Rumbaut and City on the Edge: the Transformation of Miami, by Alejandro Portes and Alex Stepick. I apply theories from Portes and Rumbaut for each wave of migration and utilize an additional theory from Portes and Stepick for the last wave.

In their book Immigrant America, a Portrait, Alejandro Portes and Rubén G. Rumbaut present different theories regarding immigrant and ethnic communities, their patterns of settlement, and their identities in a new land. These theories, while meant to explain phenomena in relation to immigration, can also be applied to the migration of Northeastern US Jews to Miami in the first wave and the subsequent communities they established. 


\section{First Wave Theoretical Framework}

Portes and Rumbaut claim it is likely that ethnic communities created by immigration will persevere and therefore become associated with and linked to their areas of settlement, giving that region a distinct cultural landscape defined by the traits of the community (63-64). The ethnic community created by immigration lends its own characteristics to the geographical area, thereby resulting in a hybrid community. This hybridization occurs when the geographical location is identified by the characteristics of the ethnic community and additionally is acknowledged by the rest of the country as the area inhabited and influenced by those immigrants. Miami demographer Ira Sheskin calls this a Jewish "ethnic homeland" (Sheskin 1993:126). An illustration of a Jewish ethnic homeland can be seen with the influx of Northeast Jews, who established pockets of concentrated Jewish areas, which included retail establishments, Jewish institutions, and by the undeniable presence of Orthodox Jews (who are easily identified by their distinct attire).

In addition, Portes and Rumbaut say that for members of a cohort of immigrants, spatial concentration will result in: "preservation of a valued lifestyle, regulation of the pace of acculturation, greater social control over the young, and access to community networks for both moral and economic support" (63-64). These ethnic communities also act as a long-lasting means for adaptation. "The apparent inclination of men...to consort with those who have the same origins provides diversity in the larger society and also creates substructures that meet many functions the larger society would be hard put to service" (62-66). This adaptation is particularly applicable to the members of the Jewish 
community, who tend to live in the same areas and within these areas, create their own foundations through which they can have their religious, educational, and communal needs met.

In my opinion, the first Jewish community established in Miami, therefore, was not only constructed to meet the needs of the new migrants, but also created a basis and foundation for a strong Jewish network, thereby increasing the number of Jews who moved to the area. As will be outlined further in this study, as a result of migration from the Northeast, Miami developed specific areas of concentrated Jewish communities. Although the authors claim that, most often, members of ethnic communities move to areas that already contain large numbers of their ethnic group, this was not the case for the Jews of the first wave. Although Miami contained a small, dispersed number of Jews, there was no organized, cohesive network or Jewish communal life, yet many migrants were drawn to the area anyway.

\section{Second Wave Theoretical Framework}

As stated previously, Portes and Rumbaut assert that when members of an ethnic community move, it is more likely that they will go to areas that already contain large numbers of their own group, including those areas experiencing out-migration. According to Merriam-Webster, the term "out-migration" means "to leave one region or community in order to settle in another especially as part of a large-scale and continuing movement of population." Outmigration occurred when the Cubans left Cuba after Castro's revolution in the late 1950s. Large numbers of Jewish Cubans moved to Miami, en masse, and relocated to the Jewish community of Miami, a city of proximity and similar climate 
to their home country. Portes and Rumbaut assert that when an ethnic group relocates en masse from its original location, it often regroups as a whole in another region (62). The authors therefore maintain that the anticipated result of these patterns will lead to specific areas of heavily concentrated ethnic communities (62). The influx of immigrants led to heavily concentrated areas of Cuban Jews, which added to the character and composition of the Jewish community. The Cuban Jewish presence in Miami was so strong that members of the second wave soon became known as "Jewbans" (Bettinger-López 2000: $3)$.

Within these concentrated communities, according to Portes and Rumbaut, religious affiliation and participation have been extremely important for many immigrants, particularly with regards to their ability to adapt to their new geographic region and handle the challenges that the new situation presents (Portes and Rumbaut 2006: 300). The often-times traumatic process of migration can be mitigated by religion. This can be seen in instances where there is no religious institution for the newcomers to practice in (or they are not accepted into existing ones), thereby resulting in the unification of the immigrant community, in order to establish their own institutions (Portes and Rumbaut 2006:303-4). While the immigration from Cuba was surely traumatic for many, religion appeared to be a uniting factor for the Jewish Cuban community, as they lived together in the same areas, established their own institutions, and eventually integrated into the existing institutions. Furthermore, the authors claim that religion acts as the most important factor in the "development of ethnic communities and the reassertion of national cultures" (Portes and Rumbaut 2006: 304). Immigrants, therefore, become American by becoming members of an existing religious institution 
and participating in its religious and community life (Portes and Rumbaut 2006:304). This is apparent even today, as Cubans have taken on leadership roles in the Jewish community previously held by non-Latinos, including Isaac Zelcer, the first Cuban president of the Greater Miami Jewish Federation and Alberto Barrocas, an active member of the Latin Auxiliary of the Miami Jewish Home for the Aged .

This theoretical framework of creating institutions where none exist is also applicable to the first Jewish community of Miami. Particularly in the 1920s and 1930s, when antisemitism was present and the Ku Klux Klan was evidently active, a community and network of institutions served to unite and strengthen the Jews of the first wave.

This network of institutions also provided the second wave a sense of security in an unfamiliar place, and served as incentive for other Jews to move to the area as well. In the same way that the first Jewish community of Miami united to build religious institutions, so did the immigrants from outside the US when they arrived. The tight-knit and cohesive institutional framework, along with participation in religious life, helped immigrants become American, some of the same factors that helped the Cuban Jews to become "Miamians."

\section{Third Wave Theoretical Framework}

According to Portes and Rumbaut, pioneer migrants had a vital influence on later migrants. As soon as a group put down roots in a particular place, it became almost inevitable that cohorts from the same country also migrated to the same place. Since migration is largely a "network-driven process" nothing appears to be as effective as the familial and relational ties to a land in "guiding new arrivals toward preexisting ethnic 
communities" (Portes and Rumbaut 2006:77-78). This assertion of established immigrant communities attracting residents from their country of origin certainly makes sense when looking at the broader picture of the history of Jewish migration to Florida, and especially applies to the third wave. While the second wave did arrive to a thriving preexisting community, they were excluded from participating in it and were required to create a subcommunity of their own. The original "pioneer community" of Jews has grown and spread to include a variety of institutions and participating members. For the third wave, the primary impetus for Jewish immigration to Miami had much to do with the lure of a thriving Jewish community, as well as a large Latin American population which already existed.

In addition, there is another theory presented by Alejandro Portes and Alex Stepick, in their book City on the Edge: the Transformation of Miami which proposes the issue of acculturation in reverse, which is a "process by which foreign customs, institutions, and language are diffused within the native population" (8). They claim that rather than assimilation to the host society, the result of a large influx of immigrants to an American city is biculturalism, a mixture of the existing and immigrant culture. This theory of biculturalism is integral to this study in explaining the results of the research, as institutions, much like the host society, are becoming more accommodating to immigrants and implementing their institutional models, which is a significant shift from the previous waves, where institutions were mainly established. While there was some hint of biculturalism at the end of the third wave, it was only until the Latin Americans immigrated in the third wave that a new hybrid identity really became more sharply defined. 


\section{Jewish Community Theoretical Framework}

According to Sylvia Barack Fishman in her book Jewish Life and American Culture, American-Jewish institutions and organizations serve as the foundations for personal, familial, and communal Jewish activities that assist in forging a sense of Jewish connectedness among individuals and social groups. In America, both religious and secular Jewish communal institutions are, for many individuals and families, the principal way in which Jewish identification is tangibly expressed. In addition, Jewish secular institutions offer a physical place and communal connection for Jews who are selfdescribed as nonreligious, to express their Jewish identity and sense of belonging within the Jewish community (153). Therefore, the institutions in Miami serve to connect, sustain, and grow the Jewish community, leading to increasingly stronger ties to each other as well as the geographic location.

As Calvin Goldscheider states in his report "Stratification and the Transformation of American Jews: 1910-90: Have the Changes Resulted in Assimilation?" there is an extensive assortment of structural and institutional features that connect Jews to one another in complex networks and distinguish Jews within the community from those who are not Jewish. These features consist of "family and social connections, organizational, political, and residential patterns, and religious and ethnic activities which can reinforce the values and shape the attitudes of American Jews" (260).

Goldscheider also claims that the shared social status among Jews and the distinctiveness of Jews in relation to other religious and ethnic groups serve as significant sources of cohesion and solidarity of the Jewish community. Jews are not only distinct 
from non-Jews, but are also linked to other Jews by "resources, networks, and life styles" (272). Community is founded upon communal interaction among members as well as a shared set of values and ways of living. Therefore, although there may be differing views and sometimes even discrimination within the Jewish community itself, due to its extensive and close-knit framework outside of the general population, the members and institutions of the community become inextricably linked and interwoven, promoting solidarity and, eventually further immigration.

Historically, in traditional Jewish communities, communal matters were interlocked with the everyday activities of Jewish individuals, families, and societies. Rabbinic law mandated that those in the community were responsible for establishing and sustaining communal institutions such as cemeteries, synagogues, ritual baths and study houses. Activities and authority within the community were strengthened by "the geographic proximity and population density that were typical of Jewish societies" (Fishman 2000:155).

However, in America in the last century, the main expression of Jewish identification has consisted of communal activities, generally through institutions and organizations. Much as in historical Jewish communities, the synagogue continued to be an influential communal structure, while for others, well-known secular Jewish organizations held more appeal. "Jewish community is the vehicle through which the abstract principle of Jewish unity and values which that unity enshrines are made manifest in contemporary Jewish life" (Fishman 2000:156). Whether they be religious or secular, Jewish institutions clearly serve as places for the Jewish community to express 
itself and come together to make the best community they possibly can. This adds to the significance of examining institutions and their effects on the community (and vice versa).

According to Steven M. Cohen in his article "Reengineering the Jewish Community", the term "Jewish community" signifies "the typical constellation of agencies found at the local level: synagogues, schools, Jewish community centers (JCCs), human-service agencies, the federation, as well as defense agencies, Zionist organizations, fraternal groups, museums, and numerous smaller, innovative endeavors" (201). These are the organizations that I will be looking at in the context of this thesis.

While the scope of this paper does not allow for further investigation into diaspora theory, I do feel it necessary to address the concept of a diasporic community. A diaspora is "the movement, migration, or scattering of a people away from an established or ancestral homeland", according to the Merriam-Webster Dictionary. The Jewish people, and its communities, have long been associated with this term, and have been creating diasporic communities all over the world. The Jews in the United States can most certainly be considered a diaspora in their own right. However, this term is particularly relevant to the second and third waves of Jews, where we see an additional layer to this concept, that of a diaspora within a diaspora. The Cuban Jews and the Latin American Jews already existed as diasporic communities in their home countries, as most originally came from either Eastern Europe or the Iberian Peninsula and settled with their fellow Jewish immigrants in those countries. Therefore, the immigration to the United States can be seen as a second diaspora, where again, a significant number of Jews from a foreign country establish themselves in new countries. As they are immigrating into an existing diaspora of the mostly Eastern European Jews who came to the United States in 
the 1800 and 1900 's, they then become a diaspora within a diaspora. This will be addressed further in the conclusion.

While the previously mentioned theories are relevant to the third wave, I feel the need to address another component of the institutional community. Recently, there has been a shift in the institutional Jewish community. JCCs and synagogues all over the county are struggling, because of a lack of attendance, lack of involvement with the community, and frankly, lack of interest. As the authors of Grande Soy Vanilla Latte state, "These individuals do not relate to a centralized Jewish community as their grandparents did or an institutional one with which their parents have been involved. Most neither recognize the acronyms of the major Jewish organizations nor can distinguish between them. They are not necessarily rejecting the institution; rather, the institutions have become irrelevant to the way young Jews are living their lives" (Berktold and Greenberg 2006:21). More institutions are reaching out to the Latin community and actively recruiting them, and the theory proposed here may give more insight into this aspect of the institutional relationship with immigrants.

\section{Summary}

Within these three distinct waves of migration/immigration, a clear and interconnected evolution of the Jewish community's institutions is presented, as well as their relationship with the existing Jewish community and with new arrivals to the community. Although each wave is unique in its own way, there are some core characteristics that remain, on their base level, the same, most notably the desire to build/participate in a cohesive community that meets the needs of its members. As the composition of the Jewish 
community changes, so must its practices, institutions, and general comportment. Just as the Jewish religion is a lived, dynamic religion, so is the community of its adherents, shifting and changing to accommodate new situations as they arise. 


\section{CHAPTER II: THE FIRST WAVE OF JEWISH MIGRATION}

The parameters by which I define the first wave of Jewish migration to Miami began in the 1920s and lasted until the mid-1950s, as determined by the demographics and the number of migrants who arrived during that time. The early migration occurred largely because of a continued economic boom and the development of the South Beach area, as well as an end to antisemitic restrictions in the hotel and real estate industries and soldiers leaving for, and coming back from, war (Moore 1992:108). When the first group of Jewish migrants arrived in Miami, not only did they have to overcome antisemitism, but they also had to establish their own communities, including synagogues, community centers, and other Jewish institutions in order to meet the needs of the community.

Within this wave, there were also smaller and less concentrated flows of migrants to Florida, most notably, a substantial number of Jewish retirees who moved to South Florida from the North/Northeast US, as well as retirees who have homes in the area where they live only in the winter months (also known as "snowbirds"). I feel it is important to mention this in order to understand the demographic and cultural influences during and in between each wave of migration. Although the snowbirds were not a permanent part of the Jewish community, they did contribute somewhat, particularly in terms of culture and synagogue attendance (Moore 1992: 108). Overall, however, the majority of migrants to South Florida consisted of adults of working age and families (Sheskin 2005a:5).

I also feel it is important to note that while there were Jews who lived in Miami prior to the first wave defined above, the Jewish presence was insufficient to build a cohesive and solid foundational community. Rather, the Jewish "community" consisted 
of many small disjointed groups of few individuals, conducting Jewish rites of passage when possible (Zerivitz, Miami's Jewish History). Therefore, I will mainly be focusing on the time period of substantial growth and development within the Jewish community, which began in the 1920s.

Throughout my thesis, I will outline the emergence of a now-established Jewish community in Miami, which I define as beginning in the 1920s. I intend to shape this outline with further information about the demographics of the Jews who came to Miami, their reasons for coming here, and what they accomplished, institutionally, during the time period of the first wave of migration.

\section{Pre-First Wave Jews in Miami}

There is very little academic work on Jewish migration to Miami prior to World War II. While there is information regarding the impetus for why Jews came to Miami and what they did once they arrived there, there is almost no work done on where they came from and why they decided to migrate to Miami. Despite the lack of a cohesive, significant population, the early Jews in Miami did attempt to fulfill their obligations to Judaism by performing different rites and rituals.

The first circumcision was commemorated in 1907, while in 1913, there was a Jewish wedding and the first Jews settled on Miami Beach. That same year, the death of a Jewish tourist forced the small Jewish community of 35 to create the first congregation (that became Beth David) and a cemetery. By 1915, there were 55 Jews in Miami, and

other organizations were formed to meet the needs of the community. With the arrival of extensive infrastructure, including better access to the city of Miami, the automobile and 
commercial aviation, abundant land, and plenty of promotion for relocating to the area, a tourist and real estate boom occurred in the 1920s. A population of $100 \mathrm{Jewish}$ families exploded to 3,500 Jews by the 1920s (Zerivitz, Miami’s Jewish History).

Despite the rapid growth of the Jewish community or perhaps because of it, antisemitism in the 1920s and 1930s in South Florida was apparent. The Ku Klux Klan freely made their presence known and school segregation was not considered uncommon. Beach signs also prohibited Jews and Blacks from swimming and hotels advertised for jobs with signs such as "Gentiles only need apply". Antisemitism greatly restricted the places in which South Florida's Jews could live during this time period (Sheskin 1993: $125)$.

\section{Early 1920s to 1930 s}

What was so attractive about Miami to American Jews was that it was so different from where the majority of them lived. Prior to World War II, over $50 \%$ of the Jewish population in the United States lived in New York and Chicago, two large and exciting, but very cold, cities (Moore 1994: 18-19). Apparently, the cramped living spaces, unattractive tenements, and snow storms could not hold a candle to the beautiful weather and expansive beaches, spread-out buildings, and lack of over-crowding that was Miami.

Marcia Jo Zerivitz, in her electronic article “Miami’s Jewish History,” relays some reasons for early migration to Miami. As Miami itself began to grow and develop as a city, so did its communities, including the Jewish community. With the advent of a more extensive and accessible transportation infrastructure, it became easier for people not only to move to Miami, but also to visit. Therefore, along with easier access, the 
sunny weather and beautiful beaches of Miami, a tourist and real estate boom was created in the 1920s. Although there was a boom and a bust, harsh weather and the Great Depression all within a decade, the Jewish community and Miami bounced back in a big way.

According to a tourist guide book on Miami by Adam Karlin, by the mid-1930s, Miami began a gradual revitalization, with new residents arriving by air, train and steamship, and the Jewish population grew to about 4,500 (23). Jews contributed to many different facets of Miami’s burgeoning economy, including hotel, banking and construction industries. The 1930 s also brought an end to the strict limits regarding Jewish ownership of real estate on Miami Beach. Since many real estate owners owed a large amount of debt on their properties as a result of the Great Depression, they were eager to sell to Jewish buyers, regardless of their feelings of antisemitism. Along with Jewish ownership of properties, groups of mostly Jewish developers began to build small, fashionable hotels along Collins Avenue and Ocean Drive on Miami Beach, triggering a "mini boom" that resulted in the creation and development of the now-famous Art Deco district (23). Not only did South Florida's improvement in transportation and infrastructure help bring visitors and migrants to the area, but the growing number of hotels and expansion in the tourist industry itself in Miami Beach made Miami a seemingly easy and desirable place to be.

\section{Community Institutional Establishment}

As previously mentioned, Jews were central in helping to develop the cities of Miami and Miami Beach, where they had large roles in the building of hotels, tourism, banking, and 
education. In 1917, the Conservative Congregation of Beth David, known as "Miami's Pioneer Synagogue" (and formerly named B'nai Zion), was the first synagogue to be established and officially incorporated, and boasts Miami's oldest congregation (Beth David Congregation). This congregation was originally created in 1912 when a group of men gathered at the home of Mendel Rippa, as there was no physical structure for them in which they could meet and pray (Olitzky and Raphael 101). In 1920, Sarah and Sol Schwartz, early settlers in the South Florida and Miami area, organized the first Chevra Kadisha, or Jewish burial society (Zerivitz 2009:19). The Temple Israel Reform Jewish Congregation of Miami was founded as the first Reform synagogue in 1922, when a group of 22 less traditional Jews split off from Temple Beth David and formed their own synagogue (Olitzky and Raphael 101). In 1924, another group of members from Beth David left to form the Miami Orthodox Congregation. Miami Beach's first synagogue, Congregation Beth Jacob, was built in 1929, on 3rd Street and Washington Avenue, since at that time Jews were not permitted to live north of 5th Street. As there was no cohesive or perceptible Jewish presence in Miami Beach at the time, the initial purpose of the synagogue was to function as the religious and social center of the Jewish community. According to the webpage "301 Washington: Miami Beach's First Synagogue”, the synagogue rapidly developed into serving as the Jewish cultural center as well, where a Hebrew school was established, and scholars, rabbis and cantors were invited (Jewish Museum of Florida). Aside from the first synagogues, the Jewish Community Service of Greater Miami was founded in 1920. As the county's first Jewish social service agency, JCS initially provided mental health, refugee resettlement, foster care and adoption services to a small but vibrant Jewish community (Jewish Community Services of South 
Florida). While this wave was not one of the most substantial, it helped to lay the beginning of a solid foundation for further development.

\section{Mid 1930s to mid-to-late 1940s}

Hoping to increase trade and visibility, Miami's political leaders persuaded the government that Miami would be the ideal place to train military recruits. Debra Dash Moore, in her book To the Golden Cities: Pursuing the American Jewish Dream in Miami and L.A., asserts that as a result of Miami agreeing to train military recruits, funding and soldiers swarmed to Miami, particularly to Miami Beach. Many of the military personnel going to Miami at that time were Jews, and many of them returned after the war to live in Miami permanently (Moore 1994:39-40).

The Army Air Corps leased the Miami Beach Municipal Golf Course for a dollar a year, setting it up as the school's headquarters and drill ground. Little by little, the army appropriated 85 percent of the Miami Beach hotels, stationing soldiers in hotel rooms (many of which were built by Jews or Jewish construction companies). Soldiers were drilled in the streets and on golf courses, restaurants were turned into mess halls, and Miami Beach itself was essentially transformed into an army base. The potential for life on Miami Beach postwar enthralled many soldiers who promised to return after the war was over. Family and friends visiting soldiers were also attracted to the beauty of Miami Beach (Moore 1994: 39-40).

After the war ended, the Army returned the hotels to their prewar owners, and the beach business began to grow and expand. While Miami experienced many temporary residents during the war time, afterwards, many of those temporary visitors became 
permanent residents, and brought along their friends and family. Not only did the GIs and their families return to the paradise they remembered, but many of those from the North also longed for Miami's sunshine, beaches, and clean air (Moore 1994: 39-40).

By the mid-1940s, there were about 30,000 Jews in the Miami-Dade area (up from 3,500 in the 1920s) and about 50 percent of them lived on Miami Beach. While the Second World War continued to escalate in Europe, Miami's small but active Jewish community began to establish institutions in anticipation of soldiers coming back from war and refugees and immigrants escaping to Miami (Zerivitz, Miami's Jewish History).

\section{Community Institutional Establishment}

Along with the growth in population came the growth of institutions such as branches of national Jewish organizations, hospitals, and an education agency. The Jewish Federation, established as a national institution in the late 1880s, was founded in Miami in 1938. The Jewish Home for the Aged (currently Miami Jewish Health Systems) was incorporated in 1940 and claims to be "the largest and most innovative provider of health care for seniors in the Southeast" (About Us: Miami Jewish Health Systems). In the 1940s, a group of Sephardic (Jews originally from the Iberian Peninsula) retiree migrants formed two communal organizations, the Sephardic Brotherhood of Greater Miami and a synagogue. By 1950, the Brotherhood had combined with the Sephardic Jewish Brotherhood of America Branch, and subsequently renamed the institution to the Sephardic Jewish Center of Greater Miami (Lavender 1993:120).

In 1944, the Bureau of Jewish Education of Greater Miami, now called the Central Agency for Jewish Education (CAJE) was established, as a way of "creating, fostering 
and nurturing a community of Jews with deep knowledge, understanding and appreciation of Jewish traditions, culture, values and heritage" (Mission Statement \& History). According to Deborah Dash Moore in her book To the Golden Cities: Pursuing the American Jewish Dream in Miami and L.A., by 1944, institutions established in Miami included eight synagogues, B'nai B'rith, American Jewish Congress, National Council of Jewish Women, Hadassah, the local Y, Jewish Social Service Bureau, and the Greater Miami Jewish Federation (90). One B’nai Brith Lodge in 1945 grew to seven lodges and nine chapters, with over 2,000 members in less than a decade (86). As the influx of Jewish migrants was fast and furious, it led to a somewhat disconnected and disorganized community, in addition to the "permanent tourist" mentality they brought along with them. As one northeastern contemporary observer stated, "The community is still new, varied, and anxious to get ahead. It has no tradition of long standing so that the basic elements of ideological quarrels are missing or shelved in favor of a constructive job." It appeared as though there was no unifying structure to hold the Miami Jewish community together (92). Therefore, despite the increasing number of institutions that were being a established, an underlying, common agenda for the entire community appeared to be missing.

\section{Mid 1940s to mid 1950s}

As the tourist industry continued to expand, it was once again revitalized by new strides in technology, including mainstream use of air conditioning, mosquito control, improvement in the airport and air transportation, and Israeli businessman Ted Arison's expansion of the cruise ship business (Zerivitz, Miami's Jewish History). The subsequent 
post-war financial explosion brought even more visitors and migrants to Miami. Many of the new inhabitants were Jews, attracted by job opportunities produced from the tourism industry.

Although the strict limitations on Jewish ownership of properties on Miami Beach ended in the 1930s, the presence of antisemitism was blatant. Deborah Dash Moore, in her book article "Jewish Migration in Postwar America", says that in 1945, many signs that were posted on the beach, advertising "gentiles only" policies, were taken down as part of the Anti-Defamation League's effort to eradicate discrimination (107). This project was undertaken by seventeen ex-service men who privately approached managers of hotels and apartments which displayed such signs. The project proved to be fairly successful, as more than half of the signs were taken down. From there, Jewish residents implored the Miami Beach city council to legally prohibit such antisemitic advertising, so as to attract Jewish visitors. The council passed the law in 1947, and although it was later nullified by the Florida courts because of a lack of jurisdiction, by 1949 the state legislature granted the city council the authority to ban discriminatory advertising. The Miami Beach council then outlawed "any advertisement, notice or sign which is discriminatory against persons of any religion, sect, creed, race or denomination in the enjoyment of privil eges and facilities of places of public accommodation, amusement or resort" (107).

While legal segregation in Florida, as well as the rest of the South, was widely accepted, the above passed law demonstrated a strong denunciation of discrimination. With the local authority on board, the passing of such a policy demonstrated an acceptance and encouragement of Jews to reside in Miami Beach. While the law did not 
eradicate discrimination against the Jews and did not apply to any establishments outside of the city's jurisdiction, it set an important precedent and made a public statement that Jews were welcome in Miami Beach (Moore 1992:107).

According to Marcia Jo Zerivitz, approximately 650 Jews arrived to Miami each month for the five years following 1950. A new house was built every seven minutes and many of the builders were Jews. All in all, again, there was a huge explosion of people moving to and visiting Miami, and the economy, infrastructure, and city expanded to accommodate such changes. In 1952, Abe Aronovitz became the first (and to date, the only) Jewish mayor of Miami (although Miami Beach has had 15 Jewish mayors) (Miami’s Jewish History).

While it is estimated that only 8,000 Jews lived in Miami prior to the war, postwar, the Jewish population increased rapidly. The total number of permanent residents in Miami Beach (Jewish and non-Jewish) alone reached 46,000 in 1950, up from 28,000 before the war. The number of Jews in the Miami-Dade area doubled in 5 years to 16,000 . In the first five years after the war, the Jewish population increased over 300 percent to 55,000 by 1950 , growing much more rapidly than the growth of the general population of Miami, which was growing at a rate of $57 \%$. Within the short period of the postwar decade, Jewish migrants (almost exclusively from the North) transformed Miami from a minor concentration of 16,000 Jews into a major urban Jewish hub of 100,000 residents. Miami soon became one of the top American cities in Jewish population. Interestingly, only 4 percent of the Jewish population had actually been born in Miami; virtually everyone had come from someplace else (Moore1994:40-41). Jewish migration represented a city-to-city movement, as most of the Jewish newcomers to 
Miami left big cities east of the Mississippi. Only a tiny fraction of Jews lived in rural areas in the mid-1950s, a pattern very different from the general US population. At this time, Jews mainly lived in urban areas, and migration did not change that. As Miami became a large, urban area, with beautiful weather and attractive beaches, Jews from other big cities with large Jewish populations, such as New York, Chicago, Boston, and Philadelphia, saw the appeal of palm trees and beaches and left their cold homes for the Miami heat (Moore 1994:41-42).

Migrants appeared to consist largely of New Yorkers, who then attempted to "replicate the familiar pattern of dispersed concentration" relocation (Moore 1992:108). The implications of replicating this pattern are that the migrants would set themselves up in concentrated pockets, dispersed throughout the area. The new residents primarily settled in two parts of Miami: the South Beach area of Miami Beach and in the Shenandoah and Westchester neighborhoods of the city of Miami. By 1955, 75 percent of the Jewish population of Miami resided in these two areas. As more and more migrants came to Miami, Jewish residents began to slowly move upward toward North Miami and North Miami Beach. These residential patterns of concentration were not only a result of restrictive housing policies, but also a result of the Jewish entrepreneurs' influence on the real estate, hotel, and construction industries (Moore 1992:108).

Miami was given the nickname of "The Southern Borscht Belt" and many joked that it had turned into a suburb of New York City. This Jewish-sounding nickname and association with New York underlined the sense of connectedness that the newcomers felt with their old homes, which contradicted the drastic change in their relocation (Moore 1992: 108-9). 
Jewish migrants chose Miami...in order to bask in the balmy weather, take advantage of economic opportunities, and escape from the constraining intergenerational intimacies of parents and kinfolk. Jews transformed themselves into individuals acting out of free choice, and they made their new (city) into open communities without clear boundaries, hierarchies, deference, structures. .. They created new patterns of Jewish communal life that upheld the centrality of the consenting individual (Moore 1994: 106-7).

\section{Community Institutional Establishment}

As Deborah Dash Moore recounts in her article "Jewish Migration in Postwar America" many of the new migrants joined the small number of established congregations-which offered special monthly or even weekly memberships to accommodate the "snowbirds"while those who found the synagogues inconvenient, unappealing or difficult to get to created new congregations (Moore 1992:110). By 1947, twenty-four congregations existed in Miami, with nineteen of them having rabbis leading the synagogues. Although this number may appear insignificant, given that the Jewish population was still rather modest as a whole, these numbers represent a considerable advancement in the establishment of the Jewish community of Miami and its institutions (Moore 1992:110)

In 1947, Temple Emanu-El (formerly the Miami Beach Jewish Center) was founded as the first Conservative congregation in Miami Beach, and its success led to the eventual creation of the Lehrman Community Day School, a "a fully integrated Jewish day school" built by the synagogue in 1960 (Lehrman Community Day School). Also in 1947, an Orthodox Jewish Day School called the Hebrew Academy opened, housed in the Young Men's Hebrew Association (Y.M.H.A is currently known as the Jewish Community Center), providing a combination of Hebrew and secular education (The Rabbi Alexander S. Gross Hebrew Academy). In 1949, Mt. Sinai Hospital was 
established, as Jewish doctors were not able to get staff privileges at any of the other area hospitals (Zerivitz, Miami’s Jewish History). Temple Hatikvah - The Homestead Jewish Center is a liberal congregation which was originally founded as a Jewish Community Center in 1952 by Jews who had moved further south and wanted to build a center of Jewish life (Temple Hatikvah / Homestead Jewish Center). The Center served as a place to connect with other Jews in the community as well as provide Jewish education for member's children. By the end of the 1950s, a more comprehensive and interconnected institutional framework was established, building upon the groundwork laid by the community in the previous decade.

\section{Summary}

The substantial growth of the Jewish population in the Northeast, where most of the Miami migrants originated, was brought on by waves of migration from Europe. After World War II, these Northeast Jews began to move to Sunbelt cities, thereby maintaining a large presence in the Northeast but as creating a significant presence in other states as well. According to Sheskin, by 1960 more than $75 \%$ of American Jews lived in five states (New York, California, Pennsylvania, New Jersey, and Illinois), with $46 \%$ in New York alone. The growth of the Jewish population in South Florida directly correlates with the decline in Jewish population in the Northeast. From a small Jewish population of 8,000 in 1940, the Jewish population of Miami grew to almost 140,000 (including snowbirds) by 1960 (Sheskin 1993:125-26).

It appears as though the expansion of Jewish suburban areas arose from a series of federal postwar policies that were passed in order to encourage general internal migration 
within the United States. In addition to this, the lack of adequate housing in the cities, the swift construction of affordable single-family homes, the extensive infrastructure programs and the easy availability of mortgages all convinced young families to establish their homes on the ever-growing peripheries of the nation's cities.

While these policies most certainly helped the process of suburbanization, the move from older and poorer city neighborhoods to newer and more affluent ones was already in play long before they were enacted. Although they no longer lived in the city, suburban Jews did not cut their ties with the city, its culture and institutions. The sustained connection with city life was especially germane for those who continued to work in the city, as well as the many who visited often. In addition, suburbanization did not disturb the family unit, but rather, it expanded the reach of the intergenerational family. While Jews began to organize a new Jewish life for themselves in the suburbs, they also imported the existing Jewish institutions in the city. Synagogues often followed the more well-to-do congregants to the suburbs, giving congregants a sense of continuity and reinforcing deference to established leaders. In contrast with internal migration, no radical change in leadership or institution took place, which tended to disrupt structures of collective continuity. Moving to Miami served as an equal but alternative option to moving to the suburbs, and similarly, Miami suburbs came to be developed as well (Moore 1992:106).

As Miami's Jewish community grew, so did its reputation, and it soon became known as an "ethnic homeland" for Jews. According to Ira Sheskin, there are three decisive factors in identifying an ethnic homeland. Primarily, there must be recognition by the ethnic group itself that a particular area or neighborhood has a unique significance 
it, and the place should make the group feel as if it is "at home." Second, there must be some sort of general consensus by the rest of the country recognizing this area as also having special significance for this ethnic group. Finally, there should be a clear presence of the ethnic group in this area, so as to be unmistakable to anyone who comes to this area that it is special for this group (Sheskin 1993:119).

It can be said that Jews have viewed Miami and Miami Beach as an ethnic homeland of sorts for themselves. Similar to the Lower East Side in New York, Jews who have lived in South Florida for many years are inclined to see the Shenandoah region south of the Miami downtown area (the first area of Jewish settlement, now Little Havana) as a part of Miami's Jewish homeland, although it has not been significantly Jewish in a very long time. The Jewish presence on Miami Beach became unmistakable, especially with its concentration of Jewish institutions and retail establishments, as well as the visible presence of Orthodox Jews, who are easily identified by their unique attire, and leave no doubt about the Jewish presence. Thus, to all Jews in South Florida, and additionally, within the entire United States, Miami (and Miami Beach in particular) was acknowledged as a Jewish ethnic homeland (Sheskin 1993:125-26). 


\section{CHAPTER III: THE SECOND WAVE}

One of the big differences between the first and second waves is that the first wave consisted of steady migration (with a couple of notable spikes in the 1940s and 1950s), spread out along an approximately 40 year period, while the Cuban Jews (also known as "Jewbans") immigrated almost en masse to Miami. However, they are similar in that both cohorts, upon arrival to Miami, had to cultivate their own community, establishing their own institutions with little or no help from the existing communities. According to Bernardo Benes, a founding member of Miami’s Jewish Cuban community, the Cubans were required to create their own institutions as they were essentially ignored by the local Jewish community. The Cuban Jews appeared to receive little assistance from the existing community, neither financially nor through moral support (BettingerLópez 2000:3).

Within the two years following Fidel Castro's revolution and subsequent takeover in Cuba (1959-60), 70 percent of the Jews residing in Cuba left, because of discord with the revolution's ideology, as well as fear of discrimination, persecution, and antisemitism (Bettinger-López 2000:xxxviii). While not all of these Jews immigrated to Miami, a large percentage of them did. Cubans of all different religions had been vacationing in Miami during the summers before the revolution, as prices for hotels and restaurants were lower than they were the rest of the year. Many local Miamians called this the "Cuban Invasion," and thus the familiarity with the city, similarity in climate to Cuba, as well as proximity led to Miami as the top choice for immigration (Liebman 243). In addition, a large percent of the Cuban Jews particularly settled in Miami as there was already a sizeable, existing Jewish community (Benz 69-70). The Cuban immigration settlement eventually 
changed the composition and configuration of the Jewish community, after an initial mini-wave and subsequent wave of immigrants arrived in Miami. Although there is no exact figure, some say a mini-wave of approximately 2,000-3,500 Cuban Jews originally came to Miami temporarily, anticipating a temporary exile in the United States, and therefore were not interested in establishing their own institutions and communities. Within a couple of years, the Cuban Jews came to the conclusion that they would have to put down roots in Miami, and therefore began establishing themselves as residents. They had to rebuild their lives, including reestablishing their careers and livelihoods, as well as adjusting to a foreign and often unfriendly environment (Benz 69-70). The number of immigrants grew exponentially after the initial influx, growing to around 5,000 by 1965 (Bettinger-López 2000:36), which one could claim also contributed to the intolerance of the new immigrants by the Anglos.

\section{Discrimination}

As previously mentioned, the Cuban Jews were mostly unwelcome and/or ignored in the Jewish community of Miami. The possible reasons for this vary, and as little information on this matter exists, it can only be speculated upon. According to Rabbi Meyer Abramowitz, one of the only rabbis to welcome the Cuban Jews into his synagogue, Temple Menorah, this was a result of the assumption of the American Jews that "Cuban Jews were wealthy and so did not need economic or social assistance" (Bettinger-López 2000:23). Also there is a high likelihood that the general anti-Cuban sentiment in Miami at the time paralleled (and perhaps affected) the Jewish community. Ironically, the discrimination suffered by Cubans in the 1960s is similar to the antisemitism suffered by 
the Jews in the 1920s, including signs posted in buildings saying "No Pets, No Kids, No Cubans" (Rich 1996:148).

There seems to be a general consensus that many of the Cuban Jews who arrived in Miami were trained and educated professionals who made good money in Cuba. However, there are differing opinions on the economic state of the Cuban Jews upon arrival to Miami. Although there appeared to be an assumption on the part of the existing Jewish community that the Cubans Jews who arrived in Miami had brought their fortunes with them, most of the Cuban Jews did not have any resources outside the island and were not able to bring their money to the United States (Bettinger-López 2000:4). Once they immigrated to the United States they were forced to take menial, low-paying jobs. Then, slowly, as more Cubans began to establish themselves and build social and economic capital, they were able to not only survive, but thrive as well (Heisler-Samuels).

Just as the first Jewish migrants encountered discrimination and were compelled to form and establish their own communities, so did the Cuban Jews. Most attempts to be included in the Jewish community were rebuffed. The existing American population of the Miami Jewish community, which consisted of mostly Ashkenazi (Jews of Eastern European descent) Northeasterners, largely ignored the Cuban Jews and failed to absorb them into the community (Bettinger-López 2000:4). Although the Jewbans were largely Ashkenazi, there were a sizeable number of Sephardim (Jews from the Ottoman Empire) who immigrated as well. And despite the prior existence in Miami of Sephardim who had established their own communities and synagogues, there was still an "anti-Jewish Cuban" sentiment and unwillingness to accept the Jewish Cuban exiles living in Miami (Bettinger-López 2000:6). According to Bettinger-López, many Cuban Jews moved to 
Miami Beach specifically to create bonds with the existing Jewish community; however they were greeted with coldness and indifference. The first mini-wave of an estimated 2,000-3,500 Cuban Jews who originally immigrated to Miami were disapproved of and even resented by the successful, well-established Jewish community. In one opinion, these émigrés were seen as poor and considered to be detrimental to the population, a drain on society and a dilution of the well-to-do community the Northeast Jews worked so hard to establish in Miami (Bettinger-López 2000:26). As previously mentioned, in another opinion, there was another faction of the existing Jewish community that saw the Jewbans as prosperous and therefore not requiring assistance from the Jewish community. Regardless of the perspective of the American Jews in Miami, each used their own view point as a reason to exclude the Cuban Jews from their communities and city.

\section{Composition of Community}

As previously stated, the composition of the Jewish community, to an extent, was already sub-divided into Sephardim and Ashkenazim. According to Seymour Liebman, the Cuban Jews who immigrated to the United States were also sub-divided; however, they consisted of three distinct groups: Sephardim, Ashkenazim, and the younger generationunder sixteen years of age—of both groups (Liebman 1969:243). The youth, who were exposed to and associated with other children at school, adapted quickly to the culture and community and associated with every type of Jew. Any differences in background or practice were of little importance to the younger Jews. Since the majority of the existing Jewish community was Ashkenazi, in general, the Ashkenazi Cuban Jewish adults and children were not particularly distinctive from the existing Jewish community in terms of 
appearance and religious practice. Conversely, according to Liebman, the Cuban Jewish Sephardim were even more of a minority, and were distinguishable because of their "olive complexion, their volatility, emotionally and otherwise, and their strong adherence to tradition" (Liebman 1969:243). They often lived in areas separate from other Jews, both the existing Jews and the Ashkenazi Cubans, in order to preserve their distinctive lifestyle and customs.

Despite this distinction, many Sephardim and Ashkenazi came together to create a community for themselves. Although each faction established their own specific institutions, they mixed and inter-mingled, socially, culturally, and religiously, seemingly without any difficulty (Bettinger-López 2000:36-7).

In terms of religious life, According to author Seymour B. Liebman, the Cuban Jews had an equally strong affiliation to Jewish institutions, particularly synagogues, and maintaining their Jewish life and identity as the American Jews (Liebman 1969:243). Therefore, upon arrival, the Cuban Jews were intent upon locating synagogues and Jewish schools or educational institutes where they and their families could resume and maintain a Jewish life. Much like the existing community, identification with Judaism was much stronger and more important than actual adherence to Jewish law. Despite this emphasis on identity, it was of utmost importance, as was the case with the American Jews, that their children receive a Jewish education (Liebman 1969:243).

\section{Community Institutional Establishment}

Because of the reluctance to acknowledge and integrate the Jewish Cubans into the "mainstream" and existing Jewish communities, the new migrants decided to take 
matters into their own hands and create their own organizations and institutions. This empowerment of the Cubans led to the formation of alliances such as Temple BethShmuel (also known as the Cuban Hebrew Congregation of Miami) for the Ashkenazi Cubans and Temple Moses, the Cuban Sephardic Hebrew Congregation.

Temple Beth-Shmuel was founded in order to provide a home for those Jews that emigrated from Cuba. In 1961, 13 people gathered in the Lucerne Hotel in Miami Beach as the first step in forming the Círculo Cubano Hebreo, which later became Temple Beth-Shmuel (Cuban Hebrew Congregation-Temple Beth Shmuel). This small group eventually flourished into a large congregation with a physical building, holding social functions, Sabbath and holiday services, adding a Hebrew school for children, and creating a women's club, or Sisterhood.

Religious services were led by Rabbi Dov Rosenzweig, offering a place for Ashkenazim to come together to pray. With another branch in South Beach, the Círculo served the needs of those in the community who wanted a place to pray, a place to congregate socially, as well as an educational institute for their children. The Círculo was the largest social center for all shades of Cuban Jews, with over 700 member families. It also conducted weekday classes for some 20 children with a staff of three teachers. Religious affiliation of the more affluent Ashkenazim was centered in the North Shore area. The few Orthodox Jews belonged to congregations close to their homes. The American Jews and those who belonged to the Reform Temple in Havana were affiliated with Reform temples in South Florida. However, with the exception of the Conservative Temple Menorah, more Cuban Jewish children attended the Orthodox all-day Hebrew Academy than any other single school. Their parents saw no conflict between the 
Orthodox education their children were receiving and their much less rigid religious observance at home. (Liebman 1969:243-5)

In 1965, the congregation even set up a table at Opa-Locka Airport to welcome refugees coming from Cuba (“Cuban Hebrew Congregation Timeline”). The Círculo established the Comite de Damas, or Women's Committee, in 1962, reinstating many of the formerly active non-religious committees of Cuba, dedicating to helping out others in their own community as well as in Israel. "Continuing to carry out these social and charitable functions, the Comite de Damas served both as an important link to the former Jewish community of Havana and as a means of realizing, in the group's new home, many of the Circulo 's extra-community objectives....the committee's main function was to help unite the Cuban-Jews of Miami” (Bettinger-López 2000:53).

Most other synagogues, including existing Sephardi congregations, required some sort of payment for services provided, which offended and repelled the new immigrants. To counteract this, the Cuban Sephardim organized the Cuban Sephardi Hebrew Congregation, which later became known as Temple Moses. In 1968, Temple Moses was officially established as an orthodox Sephardic congregation which incorporated traditions and customs brought from Turkey and Cuba by its founders (Temple Moses). Rabbi Nissim Maya, the son of the chief rabbi of Havana, became Temple Moses' first rabbi, a learned man who was a professor of Hebrew, a cantor, and a mohel (a person who performs ritual Jewish circumcisions). Temple Moses was intended to be a both social and religious institution for the Sephardic Jews. Initially, it had a membership of 150 families, a Macabbi (sports activities), a Hevra Kadisha (burial society) and offered Hebrew school classes for children (Bettinger-López 2000:77). 
Although the Sephardim and Ashkenazim originally began to build a Jewish community for themselves together, a Cuban Sephardic community emerged from this original Cuban Jewish community. In fact, this new community was founded in part by Sephardic members of the Board of Directors of Temple Beth Shmuel, an Ashkenazi synagogue. While the Cuban Sephardi Hebrew Congregation replaced Temple BethShmuel for a number of Sephardim who were members of Temple Beth-Shmuel, many members of the community retained multiple memberships to synagogues, both Ashkenazi and Sephardi (Bettinger-López 2000:66).

According to Bettinger-López, by 1966, the Cuban-Jews had also formed a "Cuban Hadassah" (a women's group) and made their presence so ubiquitous with the local Jewish community that in 1966 the Greater Miami Jewish Federation created a "Cuban Division," particularly as many Cuban-Jews were increasingly becoming part of the Federation's Board of Directors (Bettinger-López 2000:48-9). In this way, Cuban Jews were able to contribute to and play a part in Jewish life in Miami and concentrate on vital issues confronting them, like migration from Cuba and community development. This integration was part of the transition of the Jewish community to becoming more accepting of the Cuban-Jews and integrating them into existing frameworks. Fairly quickly, by the mid-1960s, Cuban-Jewish organizations such as synagogues and social groups became increasingly influential entities, and contributed to the religious, social and charitable aspects of the Jewish community, gaining respect and admiration, along with a willingness to work together with the existing non-Cuban institutions (48-9). 


\section{Transition and Integration}

One exception to the rule was Temple Menorah. Founded in 1949 as the North Shore Jewish Center, Temple Menorah, a conservative synagogue, served as a place to "gather, worship and study" for the burgeoning Jewish community (Temple Menorah History 2012).

While the majority of the Jewish community appeared to ignore the Cubans (and vice versa), Temple Menorah was one of the only synagogues that actively welcomed the Cuban migrants. Many Cubans settled in North Miami because of the presence of Temple Menorah, which not only tolerated the new immigrants, but encouraged them to be members of the synagogue and the community. At Temple Menorah, Rabbi Abramowitz offered the Cuban exiles free synagogue membership and Hebrew school as well as seats for the High Holidays, allowed use of the facilities for social and political meetings, and even created a song called "Havana Nagila," a Cuban rendition of the Hebrew song "Hava Nagila" (Bettinger-López 2000:3-5). This practice of offering free services to the Cuban immigrants lasted for 5 years, and as a result, 10 years after the first Cubans began attending, 80\% of the congregation was made up of Cubans (Liebman 1969:244).

Bettinger- López neglects to speculate as to why Rabbi Abramowitz was so accepting of the Cuban Jewish immigrants, although there appears to be an underlying implication that, as a rabbi, he was concerned for and with Jews in general. While this is most certainly part of it, it is also possible that Rabbi Abramowitz took this opportunity to build (or rebuild) his congregation by copying the Latin American Jewish institutional model of centralization, providing all services to the Jewbans. Although it is unclear exactly why Rabbi Abramowitz was the only clergyman to accept the Jewbans, it is apparent that with 
his foresight and accepting nature, the then recent refugees were able to build upon an existing framework, appropriate it in order to make it their own, and thrive. Therefore, this was not only an exception to the rule of shunning the Cuban immigrants, but also a template for the later integration of the Jewbans into the established Jewish community and its institutions. This acceptance of immigrants by an institution is distinct from the first wave, as those Jews had no framework in place, and had to create and establish their own institutions.

\section{Summary}

Temple Menorah in particular served as a vital institution in the transition from the first wave to the second wave and from the second wave to the third, and is demonstrative of a shift in the dynamic and composition of the Jewish community.

There is a clear distinction between the end of the first wave and the end of the second wave. By the end of the first wave, the Jewish community of Miami had established its own network of diverse institutions, in order to accommodate the needs of the community. These institutions were open to anyone in the Jewish community who wanted to utilize them. As a result of discrimination, the Cuban-Jews were mostly not given access to these established institutes, and were left to found their own organizations. However, while the majority of the second wave echoed the first wave in terms of establishing institutions the difference is that a framework within which the Jewbans could eventually insert themselves already existed, and there were a few established institutions which provided for the immigrants. This existing framework helped the Jewbans to better become part of the Jewish community as a whole, and by the end of the 
second wave, major existing institutions were integrating the Cubans into their networks. First wave Jews began to participate in Jewban-established institutions and first wave institutions began to make space in their agendas, and thus, the community, for the Jewbans to create a place for themselves. The evolution of the community created by the Jewbans paved the way for the third wave of immigration, the Latin Americans, who not only have a strong framework present that includes a Latino presence, but arrive to a community that has overcome much of its discrimination, particularly of Latin Americans. Although I have developed my own conclusion regarding the dynamic between the members of the first and second waves, much of my conclusion is based on a book on the subject by Caroline Bettinger-López. As this is the only comprehensive and ethnographic story of the Jewbans, without any corroborating evidence, it is difficult to say definitively that the information presented about the members of this wave is accurate. While Bettinger-López has drawn a very descriptive and methodical picture of the Jewish community and the Cuban Jews who immigrated to Miami, I feel that there is much more to the story. I believe that many other aspects factor into the dynamic between the immigrants and the existing community, such as economics, social class, and the receptivity of Miami as a city to the influx of immigrants. While this would be interesting for further research, as well as a compare/contrast of Jewish communities in other cities experiencing an influx of Jewish immigrants, this is beyond the scope of this thesis. 


\section{CHAPTER IV: THE THIRD WAVE}

"In Latin America, when you have 3 Jews, you have 4 synagogues"

\section{Susana María Goldbloom*, Coordinator for Jewish Communal Institution}

The third wave of Jewish immigration to Miami that I identify is that of the Latin Americans, which does not include the Cubans described in the previous chapter. For various reasons, mostly political and economic, since the 1970s there has been a large influx of Nicaraguans, Argentineans, Colombians, Brazilians and Venezuelans. Although distinct from the other waves, the current wave has built upon and utilized some of the components from the first and second wave establishments in order to help shape their new community in Miami.

The first substantial wave of Latin American Jews to immigrate to Miami was from Peru, between 1968 and 1974. The next large-scale group to make the move was the Argentines, who arrived largely between 1975 and 1980, although many returned to their home country after the recovery of the economy in Argentina (Schoer Roth). Many Argentineans sought refuge in Miami again after the bombings at the Israeli Mutual Association of Argentina (AMIA) and the Israeli Embassy in Buenos Aires in the late 1990s, and many immigrated after the economic crisis of the early 2000s. Colombian Jews have come in smaller waves, in 1980, 1990 and 1999. A significant number of Central Americans also immigrated to Miami, primarily between 1985 and 1990. And more recently, there has been a greater influx of Chileans and Venezuelans (Schoer Roth).

*Name has been changed to maintain anonymity of informant 
These Jewish immigrants are just a small portion of the overall (non-Jewish) movement from Latin America to the Miami-Dade area. Because of political and economic instability, many Latin Americans, particularly the wealthy and upper class, are seeking permanent residence in the United States — primarily in South Florida (Chardy). This mass Latino immigration provides additional motivation for Jewish immigrants to move from Latin America to Miami, as the culture and life in Miami is being heavily influenced by this influx of immigrants. This immigration is also consistent with Portes and Rumbaut's assertion that [im]migration is mainly a "network-driven process," where ties to family and country of origin guides "new arrivals toward preexisting ethnic communities" (77-78).

There is no recent demographic data on Latin American Jews living in Miami. According to the 2004 Greater Miami Jewish Community Study done by demographer Ira Sheskin, $10.3 \%$ of Jewish adults (or about 9,500 individuals) considered themselves to be Hispanic Jews, in contrast to the 4.6\% surveyed in 1994 (Sheskin 2005b:4-22). The survey also showed $29 \%$ of Jewish adults who are Hispanic Jews come from Cuba; $18 \%$, from Argentina; $16 \%$, from Colombia; and 15\%, from Venezuela. In total, 57\% of Jewish adults who are Hispanic Jews come from South America (Sheskin 2005b:4-23). Additionally, $30 \%$ of new households are Hispanic households, compared to $8 \%$ of longer-term households (Sheskin 2005b:4-49). While interim surveys are sometimes conducted within the decade between community surveys, due to the scope and cost, there will be no further data from Dr. Sheskin regarding this demographic until 2014 (Sheskin, Director, Jewish Demography Project 2012). Despite this, it is apparent that 
Latin Jews have been making Miami their home, with more than 3,000 arriving between 2001 and 2003 (Nathan).

Unfortunately, there is no more recent, up-to-date information on the current population of the Latin American Jews in Miami, nor has any scholarly research been done on this topic, as mentioned previously. In order to make my case, along with these data, I use additional information gathered from informants as well as any work done or articles written on this demographic, in addition to researching the institutions themselves.

The reasons for Latin American immigration of Jews to Miami can be attributed to a variety of factors, and is unlike the experience of the Cuban Jews who first starting immigrating en masse to Miami in the late 1950s. According to Juan Dircie, the associate director for the American Jewish Committee Latino and Latin American Institute,

If there were no Jewish community, they [Latin American Jews] wouldn't come. But they like that there is a vibrant community that is open and flexible to accommodate them, which is not the same when the Cubans came. The Cubans arrived at a much more rigid society, which was not open to them. This is not the case with the current wave of Latin American Jews, where the majority of synagogues are very interested in opening their doors and welcoming them and want their membership and are a great component to add to their demographic. The most important reason for why Latin American Jews came to Miami is because it's a place with a huge Latino population and there is a vibrant Jewish community. Those are the two big factors that make Miami such a target for Latin Jewish migration. One without the other would not make it as appealing for them to move to Miami.

For the most recent wave of immigrants from Latin America, the evolving cultural landscape of Miami and existing Jewish institutions and organizations are set up in such a way that the relationship between the established community and the new migrants has changed dramatically. The first two waves of migrants had to create their 
own communities to fit their collective needs in the face of discrimination and lack of resources. The latest groups of immigrants coming from Latin America to Miami are in a unique situation. Because of the increase in Latino immigration in Miami overall, in addition to the well-established Cuban associations, the Spanish-speaking newcomers no longer need to create their own institutions in order to be immersed in or accepted into society or the mainstream community, nor do they necessarily have to learn English to integrate with the existing community, as the Jewbans did. While this most recent wave of new immigrants do not necessarily need to establish their own institutions, they do help to implement programs within these institutions, using the Latin American model of institution, which differs significantly from the existing American model.

This is consistent with Portes and Stepick's theory of acculturation in reverse, where "foreign customs, institutions, and language are diffused within the native population" (1993:8). One of the core elements of their theory is not that the new [im]migrant population assimilates to the host society (in this case, the existing Jewish community), but rather, that it lends itself to an amalgamation of practices and cultures, resulting in biculturalism, a mixture of the existing and immigrant culture. This hybridization can be seen in the implementation of Latin American institutional models in existing Jewish institutions. The new immigrants, therefore, have no need to establish their own Spanish-speaking institutions, as their needs are being accommodated, to an extent, by the existing institutions.

According to Susana María Goldbloom, coordinator of the Latin American department for a local Jewish communal institution, this model, for the majority of Jewish communities in Latin America, consists of one central agency that is in charge of 
all Jewish communal activities. In order to be an active member of the community, one must pay their dues to the central agency. If this is not done, then the services provided by and through this central agency are not available to those in the community.

Without paying dues [to this central agency], it is not possible to participate in the community, and reap the benefits of the community without going through this central agency. This gives you the ability to hire a rabbi, get married at a synagogue, have a plot at the Jewish cemetery, etc. It is important that everyone participate in the community at the same level, which is in contrast to the American model of having individual synagogues and agencies that are utilized.

In paying dues to the central agency, members get access to the synagogues in the community, as they are grouped under this umbrella institution. Centralized through this agency, usually called the Jewish Association of (city name here), it is comprised of Sephardim, Ashkenazim, Conservative Jews, etcetera. The other Jewish institutions, such as homes for the elderly, education, and social clubs are all managed by one community, by this one centralized organization. The centralization of institutions and services serves as an alternative to the American model of competitive institutions.

The willingness of the existing Jewish community to incorporate Latino elements to existing frameworks can also be seen in the implementation of many Spanish-speaking services and events, as well as the hiring of rabbis from all over Latin America, in order to cater to the changing demographics of the Jewish community in Miami. According to Sabi Behar, a Peruvian Jew in the community,

The Latin American Jewish infrastructure in Miami gives the Latin American Jew the opportunity to use social [structures] very similar to the ones in their own countries...The most difficult thing about immigration is the change, and the less you have to change the easier the transition (Shoer Roth). 
According to Juan Dircie, the Latin Americans arriving to Miami come with a very different approach to Judaism and Jewish life. They focus more on Jewish culture, a cohesive and active community, and Zionism and put much less emphasis on religious activity and membership to synagogues, as the American Jews tend to do.

To accommodate the interests of the [Latin American Jewish] population, organizations change. The model of affiliation to the synagogue is a veryAmerican model. To pay for a year to a synagogue is your main connection, which is not the case in Latin America. In Latin America, Jewish life is very much more into cultural issues, sports issues, Israel, and Zionism identification, not necessarily through synagogue or religious membership.

He asserts that what is happening with the arrival of Latin Jews is an attempt to replicate some of the institutional models that currently exist in Latin America. Susana María Goldbloom echoes Mr. Dircie's claim. She confirms that the Latinos who move to Miami already have a very strong sense of community and community experience, and had taken on many leadership roles in their country of origin. Because Latin Americans have a completely different structure in community development, in her opinion, the existing community is looking to them to blaze a trail for this new generation of Jews in Miami.

She claims that the institutions are not necessarily accommodating the Latinos, but rather, that they are seeking them out.

I think the institutions are looking to involve Latin American people because they know we [Latin Americans] have a huge sense of community and [they] try to recreate what we [Latin Americans] had in our countries. It's not that they [the existing Jewish community] are accommodating; it's that they are looking for us. They see that the growth of the [existing] community is going to come from the LA population. 
The Jewish institutional community sees that the growth of the community is going to come from the Latino population, and they are actively looking to tap into that. Due to the fact that Jewish communities in Latin America are usually a minority and very often face discrimination, they have a very deep-seated sense of Jewish identity, which includes community, and very strong ties to Israel. Ms. Goldbloom maintains that with regard to expressing Jewish identity, Latinos differ in that they are Jews first and then national citizens, whereas in the United States, they tend to consider themselves American first and then Jewish. She also alleges that the institutions are seeking out the Latinos because they realize the value that they will bring to the community. The institutions are trying to make them part of their evolution by incorporating the Latino community-based model.

Part of Ms. Goldbloom's job is to educate newcomers as to how the model works here, while incorporating the values and models that the immigrants themselves bring from their own communities. This is beneficial for both the new immigrants as well as the existing community.

The goal, according to Juan Dircie, is to bring these models to Miami to integrate them into the existing Jewish organizations, thereby reshaping the institutions to reflect the values and patterns that were common for the immigrants in their country of origin in Latin America. This is, in effect, shaking up the entire paradigm of what Jewish institutional life consists of and focuses on, partly by trying to replicate the Latin American standard in America. 


\section{Community Institutional Establishment}

As previously mentioned, the third wave did not contribute much in terms of establishing brand new institutions, but they tend to take over from where the Cubans left off, by integrating with the larger Jewish community. In 1972, at the beginning of the third wave, Temple Moses established a branch of FeSeLa, the Federacion Sefaradi Latinoamericana, or the Sephardi Federation of Latin America. This committee is the first, and currently only, branch of FeSeLa outside of Latin America, primarily due to the large number of Sephardic Latinos immigrating to Miami. According to the "Our Community" page on their website, it was established in order to "preserve our roots and traditions, by offering cultural events based on our Sephardic heritage, while at the same time working with all existing Jewish organizations" (Temple Moses).

Another example of a new program springing up to meet the Latin American Jewish community's needs is Hebraica. Founded in December 1983, Hebraica was an attempt to reunite the scattered Latin American Jewish community in Miami. Soon, it became a vibrant center for the Jewish people of South Florida which welcomed any Jew who wished to join, even though its main orientation was towards the new Latin Jewish immigrants in the area.

Hebraica Youth \& Leadership emphasizes the importance of promoting Jewish identity, Jewish values, a love for Israel, and the importance of family and community. Developed to maintain cultural, religious, and social ties, Hebraica reaches out to all segments of our diverse Jewish community (Hebraica Miami).

Hebraica can be considered one of the most successful attempts at replicating the Latin American institutional model. Housed in the Michael-Ann Russell Jewish Community Center in North Miami Beach, Hebraica is much closer to the standard 
Jewish community center in Latin America. For example, the programs offered through Hebraica are modeled after the youth group model of Latin America, with a very high Zionist component, and a strong emphasis on sports, especially soccer, arguably the most popular sport in Latin America. These changes to the existing paradigm are designed to welcome the participation of Latin American Jews in a place that might not otherwise provide the opportunity for them to interact and become involved. According to Juan Dircie,

The most successful [implementation of the Latin American institutional model] is Hebraica, housed at the JCC Jewish Community Center] in North Miami Beach. There you will find an organization that is much closer to what a JCC is in Latin America. All those changes welcome the participation of Latin American Jews that would not otherwise provide that opportunity for them to interact and participate [with the Jewish community at large].

The implementation of this program, at a large and established institution, helps to demonstrate the influence and shift in dynamic between immigrant and community, as previous Jewish organizations founded by immigrants were often integrated into other, established, American institutions. Hebraica is one of the very few programs established by the Latin American Jews, since the need for them has diminished, as the population grew and established institutions began to accommodate the immigrants.

\section{Synagogues}

There are various synagogues, of every denomination, from Chabad to modern orthodox to conservative to reform, that have hired Latin American clergy, presumably in order to be more appealing to the Latin American Jews. This was not done necessarily (or only) because the synagogues want the clergy to conduct services in Spanish, but rather they 
want the Latino community to feel as though they can participate in an atmosphere that welcomes Latin Jews. Therefore, many programs are structured similarly to programs in Latin America and adhere to the same dynamic. As Juan Dircie says, Latin American Jews are helping to reshape Jewish life in South Florida, and the openness and flexibility of the Jewish community supports that advancement.

According to an article in the Jewish newspaper The Forward, there are currently an increasing number of synagogues in South Florida that have been integrating Spanish into many services. This is due to the influx of Spanish-speaking (mostly South American) members who have joined the congregations (Kay).

The Shul of Bal Harbour, a Chabad-Lubavitch synagogue community center for Jewish activities, has established JLAC - Jewish Latin American Connection, which is a program "geared for those who speak Spanish or feel more comfortable in a Latin setting to get involved in Jewish culture and bond with other Jews with similar background...[therefore] engaging in new learning opportunities and sharing with other Latin Americans, [which] will create a new sense of family and community" (The Shul of Bal Harbour 2001-2012). The Shul also offers a large range of lectures in Spanish as well as JLAC events. From this change in programming, it is clear that the synagogue is not only accommodating the Latin American demographic, but is recruiting by apparently designing their agenda to suit the Latin American demographic.

Temple Beth Am, a Reform synagogue in the Pinecrest area of Miami-Dade, founded in 1955, currently has a website in Spanish, and offers programs such as Shabat en Español, Entendiendo el Judaismo (Understanding Judaism), and Club del Libro (Book Club). Beth Am boasts a roster of programs that include religious activities as well 
as cultural and educational programs, many available in Spanish. There are also High Holiday services that are conducted in Spanish, with Spanish sermons available online. According to the synagogue's "Temple Beth Am en Español" website, the clerical leadership includes Arturo L. Kalfus, originally from Buenos Aires, who leads the Shabat en Español services, along with Eilat Schmalbach, Cantorial Soloist, and Hadassah Blum, a member of the community who assists the rabbi. The religious school also incorporates Spanish into their curriculum, and has some of the children perform what they have learned at select Shabbat services (Temple Beth Am). Additionally, Temple Beth Am often has events or services that are aimed at the entire community, but represent the Latin American population, such as "Shabbat Tropical", described on the website as follows:

Add a little salsa to your Shabbat, and experience a Latin spiritual feeling at Shabbat Tropical - Shabbat with a Latin twist. Temple Beth Am's Latin American Committee invites you to a special congregational Kabbalat Shabbat Service!

This event serves as an open invitation from the Latin American Committee to the entire congregation to participate in a Latin American-themed service, welcoming and encouraging them to experience Shabbat as the Latin Americans do (Shabbat Tropical 2012). According to Rabbi Kalfus, who has been at Temple Beth Am for the last 2 years, about 150 families out of 1300 have some sort of Latin American connection or affiliation. Rabbi Kalfus claims that the Latin American Jews in his congregation tend to have come about a decade ago or more, and are almost completely bilingual. In comparison, the more recent immigrants are largely moving to the North Miami-Dade area. The reason, according to Rabbi Kalfus, for Spanish-language services and programs 
is more to give the Latin congregants the option to attend, rather than there being a great need for it.

Temple Beth Shmuel, the Cuban-Hebrew Congregation of Miami, as discussed previously, was founded in 1961 for and by Cubans, but it was not until 2002 that a native Spanish speaker was actually hired as a rabbi for the congregation. Rabbi Hector Epelbaum, originally from Argentina, was enlisted in order to help attract Latin American families and to revitalize diminishing membership within the congregation. Since arriving at the synagogue, Rabbi Epelbaum instituted Friday night services in Spanish, which continue to this day (Kay). Rabbi Epelbaum served as the spiritual leader of Temple Beth Shmuel until 2006, and he is currently the rabbi at Congregation Beth David.

Congregation Beth David, known as the "Pioneer Synagogue", was the first synagogue to be officially established in Miami in 1912. The change in leadership has also led to a shift in the synagogue's approach to attracting and retaining members. As of 2006, Beth David began to tailor its programming and marketing to align with the shift in community demography. According to an article on the topic, "the synagogue is attempting to remake itself and adjust to the new realities of a changing Miami" (Goldbum).

According to the article, Congregation Beth David is well-situated to make the most out of the growing population, and Rabbi Epelbaum has already capitalized on this by implementing a monthly Spanish-Hebrew Friday night service (much like he did at Temple Beth Shmuel) geared toward Latinos called "Shabbat Pasion." Currently, about 
$5 \%$ of the congregation is Latin American, according to the rabbi; however, he believes that number will continue to increase (Goldblum).

Bet Shira, a Conservative congregation established in 1985, has incorporated Spanish into events such as a Meet \& Greet the Rabbi to celebrate Havdalah, the ending of the Sabbath service on Saturday night, which is "targeted towards Hispanic/Latin Jews or any Spanish speaking Jews." The Spanish translation from the promotion of the event includes the following: "I invite you to participate in this night, which is all ours. We have a lot in common, even if we are from different Spanish-speaking countries. Additionally, we invite the Brazilians to come... all are welcome. We pronounce the prayers differently than the Americans, but in the end, we are all Jews. Baruch Hashem [Bless God]" (Meet \& Greet the Rabbi 2011). While Bet Shira has yet to implement the same level of Spanish or Latin American-geared programming as Temple Beth Am, it is clearly making an effort to reach out to the Latin American Jewish community.

The Chabad networks, famously known for their mainstream recruiting style and desire to attract members, are tapping into this trend as well. When Rabbi Shloime Halsband became the rabbi of California Club Chabad, they had trouble getting 10 men together to pray. Five years later, the synagogue has nearly 400 members. According to him, the significant increase is due to recruiting the neighborhood's newest Jewish members: Uruguayans, Venezuelans, and Argentines. Halsband is originally from Argentina, and said that his focus from the start was toward Spanish-speaking Jews. The rabbi has also purchased Spanish-Hebrew prayer books and launched a Spanish-language Kabbalah class. Another orthodox synagogue, Skylake Synagogue in North Miami Beach, holds services in Hebrew, but most other functions occur in what former rabbi Rafi 
Rosenberg called "Miamese" - a blend of English and Spanish dialects. This hybrid dialect, according to the rabbi, mirrors the demographic transformations occurring in the area, as well as the new members of the synagogue. The majority of Skylake Synagogue's 85 families come from Central and South America (Alter).

Skylake Synagogue and California Club Chabad are just two of the many synagogues flourishing due to an influx of Latin American Jews. Others include Temple Beth Tov-Ahavat Shalom, a Conservative synagogue in Little Havana, Beth Torah-Benny Rok Campus, a Conservative synagogue in North Miami Beach, and Aventura Chabad, an Orthodox synagogue (Alter).

Temple Menorah, the Miami Beach synagogue which was the only one to welcome the Cubans in the 1960s, hired a full-time director of Latin programming in 2001. The director oversees the synagogue's Spanish youth group and helps coordinate activities for Spanish senior citizens. About half of the synagogue's members come from Latin America, mostly Argentina.

According to the rabbi, they wanted a Spanish-speaking full-time professional in the building. Through this, they "were among the first to respond to the ritual and emotional needs of Jews arriving from Latin America" (Alter).

\section{Communal Institutions}

In addition, there is an increase in the number of groups and committees being organized that target the Latin American Jewish population that remains outside of the religious sphere. One example of this is the Jewish Community Services of South Florida, which currently offers a program called LAMP (Latin American Program). According the 
webpage "Latin American Program [LAMP]" on Community Services of South Florida's website, the program's aim is to "provides support and assistance to recent immigrants as well as to established members of the Latin-Jewish community." LAMP's agenda includes many programs and events to help assist new immigrants. Additionally, there are three on-going groups that LAMP offers to the community, which consist of "Sólo para Mi” (Only for Me) for Latin-Jewish Women, "Sólo para El” (Only for Him) for LatinJewish Men, and "Encuentros" (Encounters) for Latin-Jewish Men \& Women 35-50 (Jewish Community Services of South Florida).

Miriam Moussatche-Wechsler, the Latin American Coordinator at Jewish Community Services of South Florida has been working with the LAMP program for the past three years and says that one of her goals was to bring the Latinos into the Jewish Community Services organization, as the board had very few Latin members. She felt it was important to change that because, as she saw it, it was the only way to make the organization more Latino friendly, not only for the Jewish population but for the nonJewish Latino population of Dade county, so that they could be present in the decision making moments (Moussatche-Wechsler 2012).

Mrs. Moussatche-Wechsler echoes Mr. Dircie's assertion that the Latin model of Jewish institutional life is being replicated and integrated within the existing community. According to her, many of the Latin Jews that are coming to Miami have leadership experience from their countries of origin, and wish to utilize that in expressing themselves religiously in the community. Because of the familiarity of the Latin American model of a central decision-making agency, the Jewish community of Miami has begun to adapt some of these practices, including implementing programs such as 
Hebraica and making a more collaborative effort to bring the community together. According to the information given by Mrs. Moussatche-Wechsler, while Miami Jewish institutional life has not fully adapted the Latin American system of centralized organizations, it appears as though they are heading in that direction.

And it is not just Miami that is recognizing the increase in Latin American Jews and their influence on the city. The American Jewish Committee chose Miami to be the first branch of the Latino and Latin American Institute out of Washington D.C. The institute's director says that "What is...important is to make sure the Latin American Jews who are here continue to be invested in their countries of origin and in the development of the Latin America Jewish agenda as they also become incorporated as new Americans and start weighing in on what's important for the American Jewish community" (Carmona).

\section{Summary}

There is a clear distinction between the institutional attitudes towards immigrants/migrants through all three waves of immigration/migration. Institutions now appear to be adjusting to accommodate the new Latino immigrants by not only adopting the Latin American institutional model, but by transforming their own programs to fit the needs of the immigrants. This trend of adaptation continues at the end of the second wave, where integration and acceptance became more standard, but takes it once step further, to accommodation and recruitment.

The implications of the volume and variety of institutions that are incorporating this model of the Jewish Latin American demographics are broad and multi-dimensional. 
It is not necessary for the migrants who have been arriving in Miami since the 1970s to unite, independently of the existing community, in order to found and fund various Jewish institutions, like the first wave, nor do they need to create their own ethnic institutions within the existing framework, like the second wave. The opportunity and options presented appear to exist because of the openness of the Jewish community to adapt the Latino model of communal institutions, in addition to the desire to expand membership and other factors.

Much like the culture of Miami has changed and adapted to accommodate the influx of Latin American immigrants, so have the Jewish institutions. The unique experience these Jewish immigrants are having is a testament to the flexibility of the Jewish culture and institutions in Miami, which are now embracing the very kind of immigrant who was given the cold shoulder in the second wave of migration. It is unclear why, at this point in time, the institutions are becoming more open to change, but it may have to do with the desire to involve more Jews in the community, as many American Jews are losing interest in Jewish institutional life. Additionally, an influx of committed, active Latinos helps to re-energize the community in a variety of different ways. The new and distinctive pattern of migration, reception, and adaptation, particularly in Miami, appears to be the new norm within the Jewish community. 


\section{CHAPTER V: CONCLUSION}

My thesis is an attempt to explore Jewish Miami's institutional establishment throughout three distinct waves of migration/immigration. In the early $20^{\text {th }}$ century, the Jewish community in Miami was very small and disjointed. However, Miami soon developed itself as a city, largely with the help of an influx of migrants from the North due to federal policies promoting outgrowth to the suburbs. As this occurred, Miami became a hotspot for young Jewish families as well as older snowbirds, which helped to establish a cohesive Jewish community of institutions.

After establishing many foundational Jewish institutions, the community in Miami truly began to thrive and grow. However, this insular community, at first shunned from participating in the larger community due to discrimination, reacted similarly to the second wave of Jews to Miami. As the Cubans arrived in Miami en masse, they brought up a lot of discrimination within the Jewish community, and were all but shunned from existing community organizations. This discrimination led to the establishment of Cubancreated and -led synagogues and different groups. With time, influence, and much effort on their part, the existing community began to integrate the "Jewbans" into their existing framework, making for a richer and more diverse community.

The relationship between the members of the first and second waves and institutions is unique and complex within the context of this thesis. The interaction between the members of the first two waves began as contentious, with much friction and rejection from the members of the first wave. It is interesting to note that those in the first wave experienced discrimination in much the same way, yet did not seem to see themselves repeating that pattern with the Jewbans. However, as the larger, non-Jewish, 
communities in Miami accepted the first wave Jews, the first wave members also eventually accepted the Jewbans. However, beyond acceptance is integration and participation, and the Jewbans, given the opportunity (as well as creating opportunity for themselves) to integrate into the Jewish community, jumped at the chance. They were not only active in existing institutions, but non-Cuban Jews became active in the Cubancreated institutions. There now exists a synergistic relationship between the Jewbans and the first wave institutions, which work together in harmony to promote and develop a more cohesive and unified Jewish communal life.

The last wave of immigrants, coming from Latin America since the 1970s, had/are having a very different experience. While it is possible that the type of Latino Jews who have come/are coming to Miami are very similar, demographically and involvement-wise in their communities in their country of origin, what has changed more than anything is the existing Jewish community in Miami. One reason could be that the community realizes the value it can derive from the Latin American model of a Jewish community, by centralizing more activities and involving the Latin Americans on the boards of organizations, as well as offering services and groups in Spanish.

The current Jewish institutional model in the United States is one of competitiveness, leaving most institutions to fend for themselves (excluding umbrella institutions), and are pieced together from individual entities to form a Jewish community. The difference with the Latin American model of Jewish institutional life is that everything is funneled, conducted, and implemented through a central agency. It seems apparent from the descriptions of these institutions that the Latin American model of cooperation and centralization is indeed different. Argentina, for example, has what is 
called Asociación Mutual Israelita Argentina (AMIA), which "remains the central Jewish institution responsible for providing a wide range of communal services, social assistance, and educational programs to Argentina's Jewish community" (AJC Global Jewish Advocacy: Latin America 2012). Venezuela follows the same concept, but reconfigures it a bit as the Confederación de Asociaciones Israelitas de Venezuela (CAIV). This institution includes five organizations: The Jewish Association of Venezuela (Sephardic), the Jewish Union of Caracas (Ashkenazi), the Venezuelan Zionist Federation, B'nai B'rith of Venezuela, and the Federation of Venezuelan Jewish Women. Also affiliated with CAIV are several youth movements and representatives from smaller communities in Venezuela (AJC Global Jewish Advocacy: Latin America 2012). These models of centralized institutional life exist in Latin American countries such as Costa Rica, Peru, Uruguay, Brazil, and Colombia, among others. This model of centralization is in stark contrast to the American model, which is one of competitiveness and individuality. While there are some umbrella agencies that exist, such as Federation, the scope of centralization that they encompass is nowhere near the level of that of the Latin American institutions. The significance of this is that it appears as though American institutions are now looking to implement this model, as a way to entice Latin Americans to join and become involved. Currently there are programs being run and developed, much like Hebraica, that serve as an attempt to replicate the Latin American model.

While my original conclusion had been solely that the institutions are accommodating the new immigrants by implementing these Spanish language programs, the reality of what is happening is actually much deeper than that. In my opinion, the big difference between the second and third wave is the receptivity of the existing 
community. I believe the Jewish community in Miami is looking to the future, and in order to grow the community, they have become more open to new ways of organizing it. The evolution of the community includes changing existing models and paradigms according to the needs of the community. This development is in stark contrast to the wave of Cuban Jews who came to Miami, as they were rejected, discriminated against, and generally shut out, even as they were trying to conform to the community, as opposed to changing it.

What is happening now is multi-dimensional, but primarily reciprocal: the desire of the existing community to evolve through and by the new immigrants as well as a desire by the immigrants to implement their model of Jewish communal existence. This relationship provides fertile ground for new and more nuanced dynamics between the community and the institutions themselves.

As mentioned previously, according to professionals in the Jewish community, there are many Latin Jews that are coming to Miami today who were leaders back in their own communities, and it is a natural shift for them to be involved on an organizational level within the community. Although it is more common in the United States for only a select number of people in the community to be involved on the board of an organization or to contribute on a leadership level, this is not the case with the Latin Americans, and it appears as though they are taking the initiative in order to shape the community to reflect their interests. Therefore, not only are existing programs changing, but new programs are being implemented to replicate the Latin American model.

Additionally, many of these programs not only assist in developing a new life in Miami, but also help to keep the connections to the immigrants' country of origin. This 
nurturing of connections then becomes a part of the immigrants' relationship with Jewish communities in general, and they become a diaspora within a diaspora, adapting a new, hybrid identity. Briefly, this idea of diaspora within a diaspora suggests that the Jews of Latin America, who originally came from other countries, are again uprooting themselves in order to better their lives. They bring with them the practices and culture from their original country of origin, in addition to the practices and culture they assumed in Latin America. These practices and culture then lead to a hybrid identity, meaning their identity is constructed based on different nationalities. The dynamic of this hybrid identity allows the Latin Jews to relate to both communities and helps them to reach out to the nonJewish Latino population as well, with which the Jewish community also feels it beneficial to engage. The Jewish community in Miami is beginning to have more of a global Jewish outlook, particularly as the number of immigrants to the city increases. Latin American Jews are a natural bridge between the Latino and Jewish communities in Miami, which have many aligned interests, such as a unified community that contains institutions which serve the needs of that community.

With regards to further research, first and foremost, a comprehensive ethnographic qualitative and quantitative study of the Latin American Jews in Miami would add a much deeper understanding of this topic. Interviews and demographic research conducted on both institutions as well as leaders of institutions and members of the community would help to paint a clearer and comprehensive picture of the reality of what is happening in the Jewish community in Miami today.

Additionally, it would be beneficial to look at the contributing factors to immigration and community establishment, such as the evolution of Miami as a city, non- 
Jewish Latin American immigration to Miami, as well as economics, politics, and social geography. The concepts of hybrid identity, as well as the issues of race, religion, and culture are all extremely complex and interconnected, and pertinent to this study, and it would be extremely valuable to explore these further.

A study comparing the experiences of Jewish migration and Jewish Latino immigration over time in Miami, New York, and Los Angeles would also lead to a better understanding of these themes.

The topic of Latin American Jewish immigration to Miami is one that most certainly warrants additional research. As mentioned in the first chapter, there is absolutely no comprehensive or scholarly research done on this particular topic, and to the best of my knowledge, this thesis is the first to compile information, analyze, and propose a framework for this cohort into one cohesive study. The situation that exists in Miami is a unique one, with so many different variables and an abundance of new elements, and it seems to be reshaping the entire American Jewish community experience. 


\section{Bibliography}

AJC Global Jewish Advocacy: Latin America. 2012.

http://www.ajc.org/site/c.ijITI2PHKoG/b.835977 (accessed July 2012).

AJC Miami and Broward.

http://www.ajc.org/site/c.ffITK0OyFoG/b.7836553/k.2FEF/AJC_Greater_Miami_and_Br oward.htm (accessed March 2012).

Alter, Alexandra. October 3, 2005. "Outreach in Spanish Grows Temple Ranks." Miami Herald.

Benz, Stephen. 2005:66-76. "Cuban Jews in South Florida: Exile Redux." In Jews of South Florida, edited by Andrea Greenbaum. Waltham, MA: Brandeis UP.

Berktold, Jennifer, and Anna Greenberg. 2006. Grande Soy Vanilla Latte with Cinnamon, No Foam: Jewish Identity and Community in a Time of Unlimited Choices. Reboot.

Beth David Congregation. http://www.bethdavidmiami.org/history.php (accessed June 2011).

Bettinger-López, Caroline. 2000. Cuban-Jewish Journeys: Searching for Identity, Home, and History in Miam. Knoxville: University of Tennessee.

Carmona, Sergio. May 31, 2011. “AJC's Latin Institute Expands to South Florida.” Sun Sentinel.

Chabad.org. 2001-2012. The Shul of Bal Harbour.

www.theshul.org/templates/articlecco_cdo/aid/440406/jewish/About.htm (accessed April 2011).

Chardy, Alfonso. August 12, 2000. "Wealthy Latin American Immigrants Seek Refuge in South Florida." Miami Herald.

Cohen, Steven M. 1998. Reengineering the Jewish Community. Praeger Publishers.

Cuban Hebrew Congregation-Temple Beth Shmuel. http://www.cubanhebrew.com (accessed April 2011).

Diaspora. http://www.merriam-webster.com/dictionary/diaspora (accessed July 2012).

Dircie, Juan, interview by Ariella Siegel. AJC Latino and Latin American Institute-Miami Associate Director (June 12, 2012). 
Fishman, Sylvia Barack. 2000. Jewish Life and American Culture. Albany: State University of New York Press.

Goldbloom, Susana María, interview by Ariella Siegel. (June 12, 2012).

Goldblum, Robert. February 13, 2007. Miami’s Oldest Shul Gets A New Beat. http://central.ujcfedweb.org/page.aspx?id=142786 (accessed March 2012).

Goldschieder, Calvin. 1993:259-75. "Stratification and the Transformation of American Jews: 1910-90: Have the Changes Resulted in Assimilation?" Jewish Population Studies (Papers in Jewish Demography) (Avraham Harman Institute of Contemporary Jewry).

Greater Miami Jewish Federation. http://jewishmiami.org/about/federation (accessed April 2011).

Hebraica Miami.

http://www.hebraicamiami.org/modules.php?op=modload\&name=info \&file=index \&info _id=aboutus (accessed March 2011).

Heisler-Samuels, Betty. January 17, 2001. "Forced to Leave Homes, Cuban Jews Thrive in Miami." The Miami Herald Internet Edition.

Jewish Community Services of South Florida. http://jcsfl.org (accessed June 2011).

Jewish Museum of Florida. http://www.jewishmuseum.com/historicalbuildings.html (accessed February 2012).

Kalfus, Arturo, interview by Ariella Siegel. Rabbi, Temple Beth Am (June 7, 2012).

Karlin, Adam. 2008. Lonely Planet Miami \& the Keys: City Guides. 5th. Lonely Planet Publications.

Kay, Julie. October 17, 2003. Spanish Services Show New Face Of Florida Shuls. $<\mathrm{http}$ ://www.forward.com/articles/6852/>. (accessed February 2012).

Lavender, Abraham D. 1993: 116-32. "Sephardic Political Identity: Jewish and Cuban Interaction in Miami Beach." Contemporary Jewry.

Lehrman Community Day School History.

www.lehrmanschool.org/index.php?submenu=History_AU (accessed December 2011).

Liebman, Seymour B. 1969:238-46. United States: Communal. Vol. 70, in American Jewish Year Book. American Jewish Committee.

Meet \& Greet the Rabbi. January 2011. (link no longer available) (accessed March 2012). 
Miami Jewish Health Systems. 2012. www.miamijewishhealthsystems.org/page/about-us (accessed June 2012).

Mission Statement \& History. 2010. www.caje-miami.org/index.cfm?pageid=67 (accessed June 2011).

Moore, Deborah Dash. (1992): 312-27. “Jewish Migration in Postwar America: The Case of Miami and Los Angeles.” Edited by Peter Y. Medding. Studies in Contemporary Jewry VIII: A New Jewry? America Since the Second World War.

Moore, Deborah Dash. 1994. To the Golden Cities: Pursuing the American Jewish Dream in Miami and L.A. New York: Free Press.

Moussatche-Wechsler, Miriam, interview by Ariella Siegel. Jewish Community Services Coordinator of LAMP (Latin American Migration Program) (June 12, 2012).

Nathan, Joan. April 9, 2003. A Little Plantain at the Passover Table. The New York Times.

Olitzky, Kerry M., and Marc Lee Raphael. 1996. The American Synagogue: a Historical Dictionary and Sourcebook. Westport, CT: Greenwood.

Out-migrate. http://www.merriam-webster.com/dictionary/out-migrate (accessed August 2011).

Portes, Alejandro, and Alex Stepick. 1993. City on the Edge: The Transformation of Miami. Berkeley: University of California.

Rich, Wilbur C. 1996. The Politics of Minority Coalitions: Race, Ethnicity, and Shared Uncertainties. Westport, CT: Praeger.

"Shabbat Tropical." Temple Beth Am. February 2012.

http:/www.tbam.org/events/2012/02/17/shabbat-services/shabbat-tropical.

Sheskin, Ira, interview by Ariella Siegel. Director, Jewish Demography Project (July 24, 2012).

Sheskin, Ira. (1993): 119-32. “Jewish Metropolitan Homelands.” Journal of Cultural Geography 13.2.

Sheskin, Ira. 2005a. "Ten Percent of American Jews." In Jews of South Florida, edited by Andrea Greenbaum, 3-18. Waltham, MA: Brandeis UP. 
Sheskin, Ira. 2005b. The 2004 Greater Miami Jewish Community Study. Demography, Storrs: Mandell L. Berman Institute North American Jewish Data Bank, Center for Judaic Studies and Contemporary Jewish Life.

Shoer Roth, Daniel. September 8, 1999: E1 Nuevo Herald section. "Dade Attracts Hispanic Jews." The Miami Herald.

Singer, Isaac Bashevis. August 20, 1989. "My Love Affair With Miami Beach.” Sun Sentinel.

Temple Beth Am. http://www.tbam.org/campuslife/beth-am-en-espa-ol (accessed April 2011).

Temple Hatikvah / Homestead Jewish Center. 2011. http://thhjc.org (accessed June 2011).

Temple Menorah History. 2012. http://templemenorahmiami.org/temple-menorah-history (accessed May 2012).

Temple Moses. http://www.templemoses.com/tpl/AU_13.php?id=12 (accessed April 2011).

The Rabbi Alexander S. Gross Hebrew Academy. 2011.

http://www.rasg.org/ExplUs2_History.html (accessed June 2011).

Zerivitz, Marcia Jo. 2009. Jews of Greater Miami. Charleston, SC: Arcadia.

Zerivitz, Marcia Jo. Miami's Jewish History.

http://jewishmiami.org/about/federation/miami_jewish_history (accessed June 2011). 